\title{
English Learning Using Pronouncing the Rhyme Method
}

\author{
Sari Rejeki ${ }^{*}$, Henny Suharyati ${ }^{*}$ \\ ${ }^{*}$ University of Pakuan, Bogor, Indonesia \\ Corresponding Author: naira.tasya@gmail.com
}

\begin{abstract}
The study aims to seek the kinds of phonological interference in the English pronounciation of teachers of North Bogor PAUD. The study is a descriptive qualitative research where data is collected by recordings, transcribing and identifying pronunciation difficulties. Based on the findings, factors such as intereference, the differences in the sound system in the two languages affect the teachers' pronunciation. It is evident in the data the teachers of PAUD experienced difficulties in pronouncing the consonant phonemes $/ \mathrm{p} /, / \mathrm{k} /, / \mathrm{g} /, / \mathrm{d} /, / \mathrm{s} /, / ð /$, and the vowel phonemes /ə/, /Æ /. Diphthongs and stress are also a source of constraint.
\end{abstract}

Keywords: interference, phonemes, diphthongs.

\section{INTRODUCTION}

Research in neuroscience and psychology have proven the importance of early childhood education (PAUD). At this golden age, children can acquire and stimulate their full potential. Reseach have also shown that at three years of age, children can acquire and master three languages. English, which is given as an additional content in PAUD is given through the medium of songs. Learning English through songs has many advantages. Some of the many superiorities are songs improve children's motivation, it is a good and fun way to learn listening and pronunciation, music with lyrics engages both sides of the brain so it becomes a powerful and motivating learning tool.

One of the disadvantange of learning English through song is that non-native English speaking teachers may have concerns regarding skills. This constraint are evident in the skills of PAUD teachers in North Bogor, specifically in the pronunciation skills. The variables in the mother tongue that hinder communication in English are caused by differences in phonetics. Most languages, for instance, do not use, or pronounce, the combination in the same way as it is pronounced in the English language.

Contrastive analysis is defined as the systematic comparison of two or more languages, with the aim of describing their similarities and differences (Johansson, 2007:1). Errors result from the interference of the mother tongue in the second language, thus errors can be predicted by analysing the differences between both languages (L1 and L2). This study looks into the differences and similarities of the English and Indonesian phonological systems in terms of the different features of phonemes. All phonemes that appear in English are analysed and compared with Indonesian phonemes. This is done to identify constraints effecting the teachers pronunciation.

The study aims to answer the following questions:

1. What difficulties do the teacher's of PAUD face in pronunciating English songs?

2. What are the reasons for the mispronunciation?

\section{Objectives of the study}

The objectives of this study are finding the causes of difficulties of pronunciation and the reasons for it.

\section{Research Significance}

Theoretically, this study will give valuabel contribution to the development of phonology, especially in applied linguistics field. Practically, this study will be valuable for PAUD teachers to understand to source of errors and most importantly how to treat them.

\section{Review Of Related Literature}

The views on teaching pronunciation. The views on teaching pronunciation changed dramatically over the last half of the twentieth century. Pronunciation instruction became somewhat incidental to a course of study. In the mid 1980s, pronunciation was key to gaining full communicative competence. Communicative competence refers to a learner's ability to use language to communicate successfully. Thus in the 1980's, one of the goal of communciative competence is 'good' pronunciation.

On the contrary, another view on the teaching of pronunciation stipulated that accent-free goal is unattainable. As English is an international language, 
speaking English with an accent is appreciated. Speaking with an accent therefore is a symbol of our heritage. Thus, a better goal of pronunciation is restated, the goal of teaching pronunciation is a clear, comprehensible pronunciation.

Factors that affect pronunciation. The factors that affect pronunciation are a person's native language, age - continued exposure in the authentic contexts, quality exposure, innate phonetic ability, identity and language ego, motivation and concern for good pronunciation. (Brown, 2001: 283-286)

Before going on further to discuss the advantage of using songs as a medium of teaching, the discussion will first go through the discussion of the practical approach of teaching children. It is the principal of why teaching English through songs are superior.

According to Suyadi and Dahlia (2014: 28), Pendidikan Anak Usia Dini (PAUD) are children between the ages of $0-6$. Theory states that the factors underlying the teaching of children are:

1. Intellectual development: centered on the here and now and on the functional purpose of language.

2. Attention span; materials must be lively and fun : SONGS!! SING!! TPR!!

3. Children need to have all five senses stimulated.

4. Affective factors: like adults they too are sensitive. Teacher must give appreciation.

5. Authentic, meaningful language: focus on the here and now. Language needs to be firmly context embedded.

Theories from Jean Piaget, Fabon, Lev Vygotsky, and Jerome Brunner will also be the basis of this reseach's theoretical framework (Cameron in Fabon www.macrothink.org/journal/index.php/ijele/article/ viewFile/3892/3180).

Jean Piaget concern was with the relation that children have with the world that surrounds them and their actions. Different factors influence children's mental development. Those factors are biological, educational and cultural, the last is socio-familiar. All of them provide children with strategies to solve problems. According to Piaget, children are active learners and thinkers, constructing his or her own knowledge from working with object or ideas.

According to Fabon, children have the desire to talk and ask questions, they want to know everything, including a different language, and teachers have the responsibility of taking advantage of this. Teachers thus, have a powerful position to make their learning of English a positive, stimulating and successful experience by making use of their desire to learn.

Lev Vygotsky mentions the importance of social interaction in the development of children cognition. Vygotsky propose ZPD - zone of proximal development. The idea of ZPD is "rather than measuring intelligence by what a child can do alone,
Vygotsky suggested that intelligence was better measured by what a child can do with skilled help. Different children at the same point in development, will make different uses of the same help from an adult". The teacher has a huge responsibility in this social interaction in order to make the most of all our students. Furthermore, Harmer (2001) listed the following: controller, organiser, assessor, prompter, participant, resource, tutor, observer. He further adds, the teacher as a performer, the teacher as teaching aid; language model, provider of comprehensible input.

According to Stephen Krashen, the best kind of language that students could be exposed to is comprehensible input, that is language which students understand the meaning of, but which is slightly above the rown production. They need something or someone to provide language which has been roughly-tuned to be comprehensible to them. And his is related with teachers as language model. If the teachers make a mistake students will keep the legacy (Jeremy Harmer, 2001:65-66).

Fabon further states that teachers should interact with children through language.

Jerome Brunner who is influenced by Piagets theory explained that language is the most important tool for cognitive growth and that chlidren can do a lot more when they receive skilled help. Bruner specified routines. The idea of routines is that it can provide opportunities for meaningful language development; they allow the child to actively make sense of new language from familiar experience and provide a space for language growth. Routines will open up many possibilities for developing language skills" (Cameron 2001:11).

Fabon concludes that children learn through routines which are based on imitation and repetition. Pupils imitate and repeat what they see and hear in the classroom, which explains why, songs are powerful teachnique for teaching children about the world and about the English language.

Thus, how do children learn a foreign language? According through theory, children learn in a natural way. They learn by being motivated, by listening and repeating, imitating the teacher through interaction.

Fabon mentions the advantages of using music particularly songs.

1. Music in general, songs in particular a tool for children's motivation.

2. Putting students at ease.

3. Songs can improve the four skills, plus memorization through repition.

4. A good and fun way to learn listening and pronunciation; i.e. phonemic differences using drills is boring, students need variety.

5. Music with lyrics engages both sides of the brain so it becomes a powerful learning tool. 
6. Songs are medium for students to learn about culture.

Another article however, mentions the disadvantage of using songs. According to Millington (2011:136) the negative sides are:

1. The difficulty in choosing the right song.

2. Some language cannot be used in spoken language.

3. Teachers must have a good repertoire of songs.

4. Non-native English speaking teachers may have concerns regarding skills

5. The language in songs unfortunately do not transfer into use.

However Millington concludes that developing a song from an activity into a task with preparation, core, and follow-up stages is one way to help transfer the words in a song into use and maximise the potential of songs as teaching and learning a tool.

Thus, Millington (2011: 138) proposes the three stages of a song as a task:

1. Preparation; ex. Show pictures, getting students ready, connecting them with the song

2. Core activity; to involve the studetns and maximize interest

3. Follow-up; build on the successful completion of the core stage. Example; use vocabulary from the songs

Millington adds that it is a challenge to select a a song to fit in the curriculum and culture thefore, the solution is adaptation and modification.

This study also considers the critical period hypothesis. The theory that in child development there is a period during which langauage can be acquired more easily than at any other time. Accorind to the biologist Lenneberg the critical period lasts until puberty (around the age of 12 or 13 years), and is due to biological development. Lenneberg suggested that language learning may be more difficult after puberty because the brain lacks the ability for adaptation. Thus, he believed, was because the language functions of the brain have already been established in a particular part of the brain; that is lateralization; the development of control over different functions $\mathrm{n}$ different parts of the brain. Simply put, a person will find difficulties sounding like a native speaker if they brain have already gone through lateralization process. One indication that a person sound like a native speaker is their pronunciation. Since PAUD students are at the age where the process of lateralization have not yet performed, pupils at this age imitate and repeat what they see and hear in the classroom. Again quoting Harmer: if the teachers make a mistake students will keep the legacy.

This study also considers the similarites and differences of English and Indonesian phological system. In 2013, a study was conducted to university students in Sulawesi. With the background of English Literature, the study analysed the phonological systems of English and Indonesian language which supply several similarities and differences. The findings show that most of the 20 students involved in this study face difficulties in pronouncing consonant

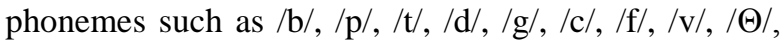
/ð/, /z/, /J/, /z/, /h/, /1/, /r/, /w/, /m/, /n/, /y/, /t $/ /, / \mathrm{d} z /$. The vowel sounds which the students experienced difficulties are the sounds: /Æ/, /əซ/, /aซ/, /eə/, and /ə/. The difficulties exist because of the differences in Indonesian and English phonological system.

Language transfer: the effect of one language on the learning of another. Two types of language transfer may occur. Negative transfer, also known as interference, is the use of a native-language pattern or rule which lead to an error or inappropriate form in the target language. Positive transfer is transfer which makes learning easier, and may occur when both the native language and the target language have the same form. (Plat and Plat, 1997:205).

Interference is a term which refers to a situation whereby two different languages overlap. Interference is either positive or negative. Negative pertains to difficulties in using the target language which are mainly attributed to mother-tongue interference. Positive - the ease or facilitation in learning the L2 resulting from similarities between the $\mathrm{L} 1$ and $\mathrm{L} 2$.

2009:321)

There are two types of interference: (Lekova,

1. Interlanguage: mistakes appear because of the negative transfer of habits from the native language.

2. Intralanguage: occurs when learners make mistakes under the influence of the already acquired language knowledge and established habits in the foreign language.

Interference of different language levels: phonetics, lexical and grammatical. Phonetic intereference affects the improper pronunciation of phonetic sounds in the second language caused by the existance of different phonetic structures.

Phonology is the study of sound systems in language. It includes phonetics, the description of sounds occuring in a language, and phonemics, the analysis of the use of these sounds to differentiate meanings of words. (Bonvillain, 2003: 7)

The English consonants. Consonants are sounds that are produced by an obstruction of an airstream either in the pharynx or in the vocal tract. Consonant is regarded as a typical speech sound that is articulated either with complete or partial closure of the air stream in the mouth cavity by means of certain speech organ. The features of consonants can be determined by three main aspects: place of articulation, manner of articulation and vibration of the vocal cords. A place of articulation deals with the speech organ involved in the production of the consonant. Based on this category, the consonants can be classified into bilabial (articulated by the lower lips), labiodental (articulated by the lower lip and the upper teeth), 
alveolar (articulated by the tip of the tongue and teh teeth ridge), post alveolar (articulated by the tip of the tongue an teh back part of the teech ridge), palato alveolar (articulated by the blade of the tongue and the teeth ridge), palatal (articulated by the front of the tongue and the hard palate), velar (articulated by the back of the tongue and the soft palate), and glottal (articulated in the glottis).

Manner of articulation deals with the way the speech organs are moved in the production of the consonants. Based on the movement of the speech organs or how the air streams is blocked by the speech organs, the consonant can be classified into: plosive (the air stream is completely blocked and suddenly released and produces a plosion), affricative (the air stream is completely blocked and slowly released, and produces a hissing sound), nasal (the air stream in the mouth cavity is completely blocked and released through the nose), lateral (the air stream is released through either both side of the tongue). Fricative (the air stream is released through narrow passage formed by the articulators and produced a hissing sound), and semi vowel (the speech organ are moved of glided from a weakly articulated vowel position to the other position).

The vocal cord may be held wide apart or closed completely. Besides, they may be held loosely together so that they vibrate when the air passes between them. During the production of the consonants, there might be more or less vibration of the vocal cords. When a stronger vibration is made during its production, the consonant is then classified as a voiced consonant, but if the vocal cord make less vibration, the sound produced is classified as voiceless consonant. When the vocal rods are tightly closed so that no air can escape at all, and they are then suddenly opened, a glottal stop will then be produced.

\begin{tabular}{|c|c|c|c|c|c|c|c|c|}
\hline \multirow[b]{2}{*}{ MANNER } & \multicolumn{8}{|c|}{ Place of Articulation } \\
\hline & & Labial & Labiodental & Inter dental & Alvedar & Alveo-palatal & Velar & Glottal \\
\hline \multirow[t]{4}{*}{ Stop } & voiceless & $\mathrm{p}$ & & & $t$ & & $\mathrm{k}$ & P \\
\hline & & pill & & & till & & kill & wh-oh \\
\hline & voiced & b & & & d & & g & \\
\hline & & bill & & & dill & & gill & \\
\hline \multirow[t]{2}{*}{ Flap/Tap } & voiceless & & & & $\Gamma$ & & & \\
\hline & & & & & butter & & & \\
\hline \multirow[t]{4}{*}{ Fricative } & voiceless & & $\mathrm{f}$ & $\theta$ & $\mathrm{s}$ & $\check{\mathbf{s}} / \mathrm{S}$ & & $\mathrm{h}$ \\
\hline & & & fine & thin & ship & pressure & & hill \\
\hline & voiced & & $\mathrm{v}$ & $\gamma$ & $\mathrm{z}$ & 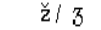 & & \\
\hline & & & vine & then & zip & pleasure & & \\
\hline \multirow[t]{3}{*}{ Affricate } & voiceless & & & & & $\breve{c} / t \mathfrak{f}$ & & \\
\hline & & & & & & choke & & \\
\hline & voiced & & & & & $\begin{array}{l}\mathrm{j} / \mathrm{d} z \\
\text { joke }\end{array}$ & & \\
\hline \multirow[t]{2}{*}{ Nasal } & voiced & $\mathbb{I}$ & & & $\mathrm{n}$ & & 3) & \\
\hline & & simme & & & sinner & & sing & \\
\hline \multirow[t]{2}{*}{ Approximant } & voiced & $\mathrm{T}$ & & & $r$ & $\mathrm{y}$ & & \\
\hline & & wore & & & yoar & your & & \\
\hline \multirow[t]{2}{*}{ Lateral } & voiced & & & & 1 & & & \\
\hline & & & & & lore & & & \\
\hline
\end{tabular}

The English Vowels, Vowels are made by voiced air passing through different mouth-shapes; the differences in the shape of the mouth are caused by different position of the tongue and the lips.

The English vowel chart:

\begin{tabular}{|c|c|c|c|c|}
\hline & & Front & Central & Back \\
\hline High & $\begin{array}{l}\text { Tense } \\
\text { Lax }\end{array}$ & $\begin{array}{ll}\mathbf{I} \text { (beat) } & \\
& \text { I (bit) }\end{array}$ & & U (book) \\
\hline Mid & $\begin{array}{l}\text { Tense } \\
\text { Lax }\end{array}$ & $\begin{array}{l}\mathrm{e} \text { (bait) } \\
\quad \varepsilon \text { (bet) }\end{array}$ & $\begin{array}{l}\boldsymbol{\Lambda} \text { (but) } \\
\boldsymbol{\partial} \text { (about) }\end{array}$ & $o(\text { paw })^{*}$ \\
\hline Low & & $\mathfrak{X}$ (bat) & & $\mathbf{a}$ (pot) \\
\hline
\end{tabular}

The Indonesian consonant chart:

Place-Voice-Manner Chart: Bahasa Indonesia

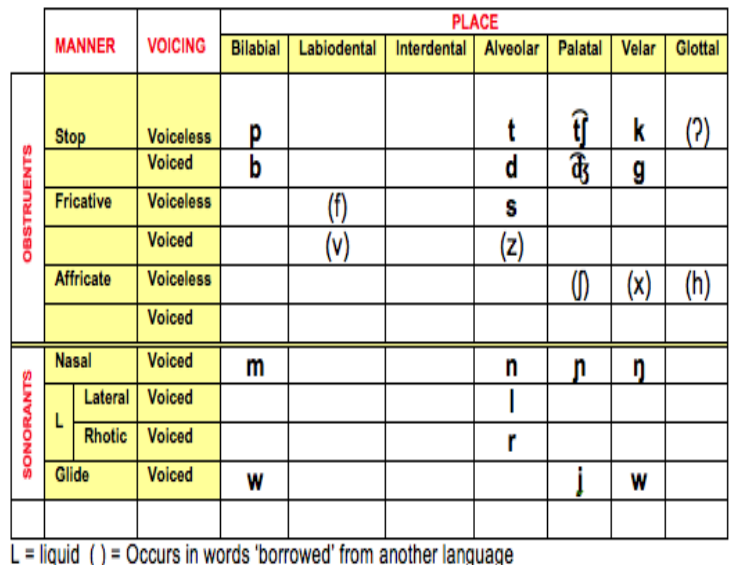

The Indonesian vowel chart:

\section{VOWELS}

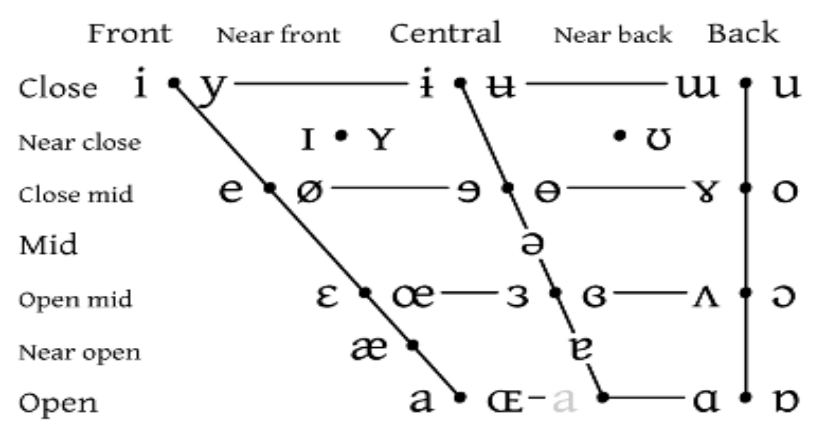

Vowels at right \& left of bullets are rounded \& unrounded.

\section{RESEARCH METHODS}

This research is a qualitative study and conducts descriptive analysis. A qualitative research is concerned primarily with process, meaning, and understanding, rather than outcomes or procedures. Therefore a qualitative researcher need to report faithfully the realities and to rely on voices and intepretations of informants. Descriptive research is designed to obtain information concerning the current status of phenomena. This study is a descriptive qualtitative study because it concerns with the natural 
context of teachers's pronounciation. Data is collected by recordings, transcribing and identifying pronunciation difficulties.

\section{RESULTS AND DISCUSSION}

In this study, the data are taken randomly from 4 teachers from North Bogor PAUD. Overall, there are 7 songs, 3 of which are "original songs", while four songs are adapted and modified.

The first song PAUD teachers use to teach English is the popular song Are You Sleeping. It is written by Frere Jacques, which is a classic nursery rhymes originated from France. Although the song has been translated to English and many other languages, it is still known under its French title. The meaning behind the lyrics clearly states the rising of someone from bed. This song is normally used to take sleeping children in loving and tender ways to prevent them from being cranky and weepy in the early morning.

Song number 1 - lyrics and phonetic transcription of Are You Sleepi

Are you sleeping, are you sleeping, brother John, brother John

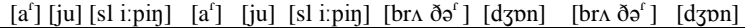
Morning bells are ringing, morning bells are ringing

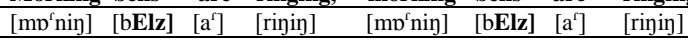

Ding, ding, dong, ding, ding, dong

\begin{tabular}{llllll}
{$[\mathrm{din}]$} & {$[\mathrm{dig}]$} & {$[\mathrm{dpg}]$} & {$[\mathrm{din}]$} & {$[\mathrm{dip}]$} & {$[\mathrm{dpg}]$} \\
\hline
\end{tabular}

Song number 2 and number 3 are adapted and modified from the song Are You Sleeping. Song number 2 introduces young learners to fruit vocabulary, while song number 3 exposes color.

Song number 2 - lyrics and phonetic transcription (adapted and modified):

\begin{tabular}{|c|c|c|c|c|}
\hline Watermelon, & water & melon, & tomato, & tomato \\
\hline [wっ:tor melən] & [wo'd & ofmelən] $^{\text {f }}$ & [təmeido] & [təmeido] \\
\hline Papaya, & papaya, & banana, & banan & \\
\hline [рәрауа:] & [pәрауа:] & [bə'næna] & [bə'næ & \\
\hline
\end{tabular}

Song number 3 - lyrics and phonetic transcription (adapted and modified):

\begin{tabular}{|c|}
\hline Red in merah, red in merah \\
\hline$[\mathrm{rEd}][\mathrm{in}] \ldots \quad[\mathrm{rEd}][\mathrm{in}] \ldots$ \\
\hline Blue biru, blue biru \\
\hline [blu:] ..., $\quad[$ blu: $\ldots$ \\
\hline Yellow, yellow kuning, ... yellow, yellow kuning \\
\hline 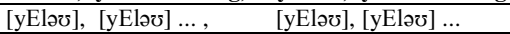 \\
\hline Green hijau, green hijau \\
\hline [gri:n] ..., [gri:n] \\
\hline
\end{tabular}

The next is the popular Head, Shoulders, Knees and Toes song. The song has been documented as early as the $1950 \mathrm{~s}$, and is often sung to the tune of London Bridge is Falling Down. Children might dance while they sing the song and touch their head, shoulders, knees, and toes in sequence while singing each word. Today there are many derivative songs that teach the vocabulary of body parts.
Song number 4 - lyrics and phonetic transcription of the Heads, Shoulders, Knees and Toes

Heads and shoulders, knees and toes. Knees and toes. [hedz] [ænd] ['Jouldə ${ }^{\complement} \mathrm{z}$ ] [ni:z] [ænd] [touz]. [ni:z] [ænd]

Heads and shoulders, knees and toes and eyes and ears and mouth and nose.

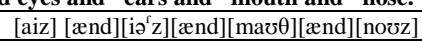

March, march, march. Let's all march. Get your body charged.

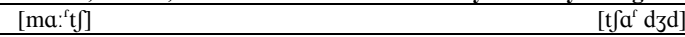

Jump, jump, jump. Let's all jump. Make your muscle pump.

$\left[\mathrm{d} 3 \Lambda \mathrm{mp}^{\mathrm{h}}\right] \quad[\mathrm{m} \Lambda \mathrm{s} ə \mathrm{l}]\left[\mathrm{p} \Lambda \mathrm{mp}^{\mathrm{h}}\right]$

Punch, punch, punch. Let's all punch. Have a hearty munch.

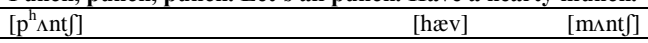

People from Indonesia know song number 5 originates from the popular Sundanese song Boneka Abdi, with the lyrics "Abdi teh ayena, gaduh hiji boneka. Teu kinten saena, sareng lucuna. Ku abdi dierokan, erokan sae pisan. Cing mangga tingali boneka abdi". This song is originated from Germany from the 19th century, known as title Hanschen Klein. The title is also tranlated into English Little Hans. It tells about a teenager who travels the world, but then comes back to his family from his adventurers. This song was very popular in the 1900 hundreds. It was the first ever song taught to children in Germany. It was taught at home and in schools. The theme of this song is adapted from the original theme, about a little child, who must never forget their mother if they leave the home. It will upset the mother if they do neglect their mother.

The song is adapted and modified. It uses animals as a theme.

Song number 5 - (adapted and modified)

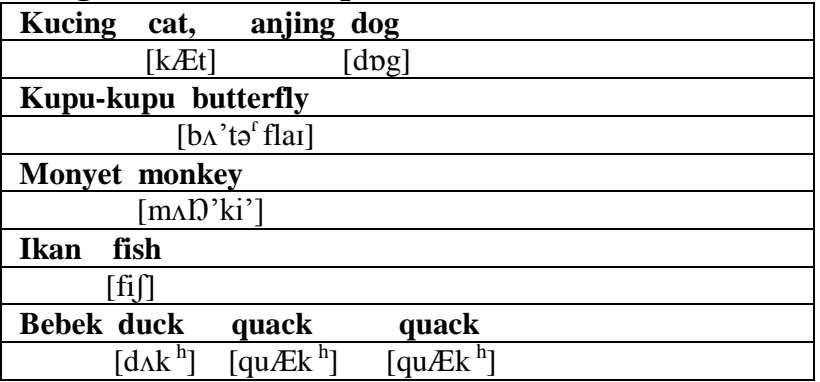

Song number 6 emphasizes the teaching of verbs such as peel, slice, eat, shake poop and the digestive system process.

Song number 6 - lyrics and phonetic transcription:

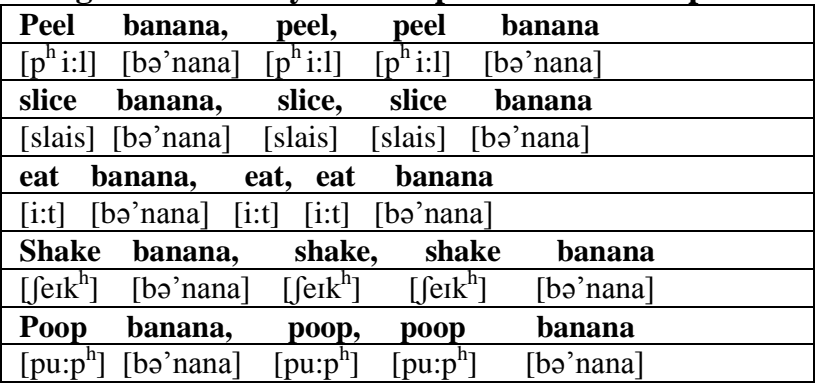


Song number 7 introduces parts of the face.

Song number 7 - lyrics and phonetic transcription

\begin{tabular}{|c|c|c|c|c|}
\hline & eyes, my & nose, my & cheeks, my & hand \\
\hline [mai] & [aiz] [mai & [ [novz] [mai] & {$\left[\mathrm{t} \int \mathrm{i}: \mathrm{ks}\right][\mathrm{ma}$} & [hænd] \\
\hline My & friend, & we clap & together & \\
\hline [mai] & [frEnd] & [wi] [klÆp $\left.{ }^{\mathrm{h}}\right]$ & 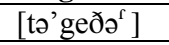 & \\
\hline Clap, & clap & & & \\
\hline
\end{tabular}

The next discussion will focus on the errors found in the pronunciation of the four teachers. The explanations of the data will be described after data number 4.

\section{Data 1 bu Erna:}

\begin{tabular}{|c|c|c|}
\hline $\begin{array}{l}\text { Mispronounce } \\
\text { d words }\end{array}$ & $\begin{array}{c}\text { Teachers } \\
\text { pronunciation }\end{array}$ & $\begin{array}{c}\text { The standardized } \\
\text { American English } \\
\text { pronunciation }\end{array}$ \\
\hline a. Red & [ret] & {$[\mathrm{rEd}]$} \\
\hline b. Watermelon & [wotermelon] & ['wote'melən] \\
\hline c. Banana & {$[\operatorname{ban} \wedge \mathrm{n} \Lambda]$} & [bə’nÆna] \\
\hline d. Tomato & [tom 'to] $^{\prime}$ & [to'metJo] \\
\hline e. Shoulders & [soldəs] & ['Soulder $z$ ] \\
\hline f. Knees & [nis] & [ni:z] \\
\hline g. Toes & [tous] & [touz] \\
\hline h. Eyes & [ais] & [aiz] \\
\hline i. Nose & [nos] & [nozz] \\
\hline
\end{tabular}

Data 2 bu Dian:

\begin{tabular}{|l|l|l|}
\hline $\begin{array}{c}\text { Mispronounced } \\
\text { words }\end{array}$ & \multicolumn{1}{|c|}{$\begin{array}{c}\text { Teachers } \\
\text { pronunciation }\end{array}$} & \multicolumn{1}{|c|}{$\begin{array}{c}\text { The standardized } \\
\text { American English } \\
\text { pronunciation }\end{array}$} \\
\hline a. Peel & {$[\mathrm{pil}]$} & {$\left[\mathrm{p}^{\mathrm{h}} \mathrm{i}: 1\right]$} \\
\hline b. Slice & {$[\mathrm{sles}]$} & {$[\mathrm{slais}]$} \\
\hline c. Eat & {$[\mathrm{it}]$} & {$[\mathrm{i}: \mathrm{t}]$} \\
\hline d. Shake & {$[\mathrm{jek}]$} & {$\left[\mathrm{sheJk}^{\mathrm{h}}\right]$} \\
\hline e. Poop & {$[\mathrm{pup}]$} & {$\left[\mathrm{pu}: \mathrm{p}^{\mathrm{h}}\right]$} \\
\hline
\end{tabular}

Data 3 bu Dwikanti:

\begin{tabular}{|c|c|c|}
\hline $\begin{array}{l}\text { Mispronounced } \\
\text { words }\end{array}$ & $\begin{array}{c}\text { Teachers } \\
\text { pronunciation }\end{array}$ & $\begin{array}{c}\text { The standardized } \\
\text { American English } \\
\text { pronunciation }\end{array}$ \\
\hline a. Sleeping & [slipin] & [sli:pin] \\
\hline b. Brother & [brada] & ['brade $]$ \\
\hline c. Eyes & [ais] & [aiz] \\
\hline d. Clap & [klep] & {$\left[\mathrm{kl} E \mathrm{p}^{\mathrm{h}]}\right.$} \\
\hline e. Friend & [fren] & [frend] \\
\hline
\end{tabular}

Data 4 bu Hetty:
\begin{tabular}{|l|l|l|}
\hline $\begin{array}{c}\text { Mispronounced } \\
\text { words }\end{array}$ & \multicolumn{1}{|c|}{$\begin{array}{c}\text { Teachers } \\
\text { pronunciation }\end{array}$} & $\begin{array}{c}\text { The standardized } \\
\text { American English } \\
\text { pronunciation }\end{array}$ \\
\hline a. Banana & {$[\mathrm{ban} \Lambda \mathrm{n} \Lambda]$} & {$[\mathrm{b}$ 'n $/$ Ena $]$} \\
\hline b. Tomato & {$[$ tom $\Lambda$ to $]$} & {$[$ to'metJo] } \\
\hline c. Cat & {$[\mathrm{ket}]$} & {$[\mathrm{k} / \mathrm{t}]$} \\
\hline d. Dog & {$[\mathrm{dok}]$} & {$[\mathrm{dog}]$} \\
\hline e. Monkey & {$[\mathrm{monkeJ}]$} & {$[\mathrm{m} \wedge \mathrm{ki}]$} \\
\hline f. Duck & {$[\mathrm{dak}]$} & {$\left[\mathrm{d} \Lambda \mathrm{k}^{\mathrm{h}}\right]$} \\
\hline g. Quack & {$[\mathrm{kwek}]$} & {$\left[\mathrm{kw} Æ \mathrm{k}^{\mathrm{h}}\right]$} \\
\hline
\end{tabular}

\section{Consonants}

The phoneme $/ \mathrm{p} /$. The $/ \mathrm{p} /$ in English appears in word initial, medial and final position, and so does the $/ \mathrm{p} /$ in the Indonesian language. It is very essential to describe here that the English /p/ is aspirated when it is in the initial position in a stress syllable. When it arises after ' $s$ ', it is not aspirated. It is aspirated when it appears in the middle and final positions. The Indonesian phoneme $/ \mathrm{p} /$ is entirely not aspirated wherever it exist in the word. Phoneme $/ \mathrm{p} /$ in Indonesian is constantly unreleased when it occurs in the final position before a pause or another consonant. Consequently, the teachers have difficulties in pronouncing the English words having the phoneme $/ \mathrm{p} /$ with aspiration.

\begin{tabular}{|l|l|l|}
\hline & English & Indonesian \\
\hline Initial & Past & Pasar \\
\hline Medial & Compass & Dipan \\
\hline Final & Tap & Kerlap \\
\hline
\end{tabular}

The $/ \mathrm{p}$ / in Indonesian is never aspirated, resulting in the mispronunciation below:

\begin{tabular}{|l|l|l|}
\hline $\begin{array}{l}\text { Mispronounced } \\
\text { words }\end{array}$ & $\begin{array}{l}\text { Teachers } \\
\text { pronunciation }\end{array}$ & $\begin{array}{l}\text { The standardized } \\
\text { American English } \\
\text { pronunciation }\end{array}$ \\
\hline Peel & {$[\mathrm{pil}]$} & {$\left[\mathrm{p}^{\mathrm{h}} \mathrm{i}: 1\right]$} \\
\hline Poop & {$[\mathrm{pup}]$} & {$\left[\mathrm{pu}: \mathrm{p}^{\mathrm{h}}\right]$} \\
\hline Clap & {$[\mathrm{klep}]$} & {$\left[\mathrm{kl}_{\mathrm{Ep}} \mathrm{p}^{\mathrm{h}]}\right.$} \\
\hline
\end{tabular}

The phoneme $/ \mathbf{k} /$. Similar to the the previous phoneme, /k/ in English is aspirated, while the Indonesian / $\mathrm{k} /$ is not. The English / $\mathrm{k} /$ phoneme emerges in three positions in the word - initial, medial and final, whilst, the Indonesian / $/ \mathrm{k}$ / phoneme just occurs in syllable - initial position. In other words, the phoneme $/ \mathrm{k} /$ in Indonesian comes out only in initial and medial positions, even though there are some words which end in the letter ' $\mathrm{k}$ '. If final ' $\mathrm{k}$ ' does happens, there are two differences in articulating it. For example. Some speakers of Indonesian pronounce it as a regular $/ \mathrm{k} /$ without being released as in English, but the majority of them replace it with a glottal stop. Consequently, it is difficult for the teachers when it appears in the initial and final positions where they pronounce $/ \mathrm{k} /$ with voiceless stop.

\begin{tabular}{|l|l|l|}
\hline & English & Indonesian \\
\hline Initial & Kit & Kira \\
\hline Medial & Tarket & Raket \\
\hline Final & Sick & Kotak \\
\hline
\end{tabular}

Similar with the phoneme $/ \mathrm{p} /$, the $/ \mathrm{k} /$ in Indonesian is never aspirated, resulting in difficulties in pronunciating words such as:

\begin{tabular}{|l|l|l|}
\hline $\begin{array}{c}\text { Mispronounced } \\
\text { words }\end{array}$ & \multicolumn{1}{|c|}{$\begin{array}{c}\text { Teachers } \\
\text { pronunciation }\end{array}$} & \multicolumn{1}{c|}{$\begin{array}{c}\text { The standardized } \\
\text { American English } \\
\text { pronunciation }\end{array}$} \\
\hline Shake & {$[\mathrm{Jek}]$} & {$\left[\mathrm{she} \mathrm{Jk}^{\mathrm{h}}\right]$} \\
\hline Duck & {$[\mathrm{dak}]$} & {$\left[\mathrm{d} \Lambda \mathrm{k}^{\mathrm{h}}\right]$} \\
\hline Quack & {$[\mathrm{kwek}]$} & {$\left[\mathrm{kw} Æ \mathrm{k}^{\mathrm{h}}\right]$} \\
\hline
\end{tabular}


The phoneme /g/. The phoneme /g/ in English exist in word initial, medial and final positions. The phoneme /g/ in Indonesian appears only in intial and medial positions. The Indonesian language has very few words ending in the letter ' $\mathrm{g}$ ', not including '-ng', and when it does appear in the final position, it is pronounced by many Indonesians speakers as $[\mathrm{k}]$ or as a glottal stop.

\begin{tabular}{|l|l|l|}
\hline & English & Indonesian \\
\hline Initial & Gain & Gamis \\
\hline Medial & Eager & Ragi \\
\hline Final & Tag & Gudeg \\
\hline
\end{tabular}

The phoneme $/ \mathrm{g} /$ at the end of the word $d o g$ did lead to pronunciation difficulty being replaced with native language counterparts $/ \mathrm{k} /$.

\begin{tabular}{|l|l|l|}
\hline $\begin{array}{c}\text { Mispronounced } \\
\text { words }\end{array}$ & \multicolumn{1}{|c|}{$\begin{array}{c}\text { Teachers } \\
\text { pronunciation }\end{array}$} & $\begin{array}{c}\text { The standardized } \\
\text { American English } \\
\text { pronunciation }\end{array}$ \\
\hline a. $\quad$ Dog & {$[\mathrm{dok}]$} & {$[\mathrm{dpg}]$} \\
\hline
\end{tabular}

The phonemes $/ \mathrm{d} /$. The phoneme $/ \mathrm{d} / \mathrm{in}$ English occurs in word initial, medial and final positions, but the Indonesian /d/ comes out only in initial and medial postion. The letter /d/ at the end of the Indonesian word is represented by the phoneme /t/ because /d/ does not emerge in the position. The teachers tend to pronounce the voiced sound [d] either into a devoiced [d] or into an unaspirated dental [t]. To know the differences of the /d/ phoneme between English and Indonesian, the following are their phonemic oppositions.

\begin{tabular}{|l|l|l|}
\hline & English & Indonesian \\
\hline Initial & Date & Daftar \\
\hline Medial & Indicate & Hadiah \\
\hline Final & Blind & Abad \\
\hline
\end{tabular}

Thus, the following errors emerge:

\begin{tabular}{|c|c|c|}
\hline $\begin{array}{l}\text { Mispronounced } \\
\text { words }\end{array}$ & $\begin{array}{c}\text { Teachers } \\
\text { pronunciation }\end{array}$ & $\begin{array}{l}\text { The standardized } \\
\text { American English } \\
\text { pronunciation }\end{array}$ \\
\hline Sleeping & [slipin] & [sli:pin] \\
\hline Knees & [nis] & [ni:z] \\
\hline Monkey & [monkeJ] & {$[\mathrm{m} \wedge \mathrm{jki}]$} \\
\hline Red & [ret] & {$[\mathrm{rEd}]$} \\
\hline Friend & [fren] & [frend] \\
\hline
\end{tabular}

The phoneme /d/ at the end of words are replaced by $/ \mathrm{t} /$ or the sound is deleted altogether.

The phoneme /s/. The phoneme /s/ in English appears on three places, and so does the phoneme /s/ in Indonesian. The English /s/ is sometimes articulated as [z] or [s]. Whilst the Indonesian phoneme /s/ is never pronounced $[\mathrm{z}]$ wherever it occurs in the word. In English the letter ' $\mathrm{s}$ ' is articulated as [z] when it comes after the letter having the voiced sound, especially in the final position, such as, peas, knickers, news, nowadays.

\begin{tabular}{|l|l|l|}
\hline & English & Indonesian \\
\hline Initial & Sack & Sakit \\
\hline Medial & Positive & Kasar \\
\hline Final & Precise & Lemas \\
\hline
\end{tabular}

The data reveal that the phoneme $/ \mathrm{s} /$ did lead to major production difficulties as shown in the table below:

\begin{tabular}{|l|l|l|}
\hline $\begin{array}{c}\text { Mispronounced } \\
\text { words }\end{array}$ & \multicolumn{1}{|c|}{$\begin{array}{c}\text { Teachers } \\
\text { pronunciation }\end{array}$} & $\begin{array}{c}\text { The standardized } \\
\text { American English } \\
\text { pronunciation }\end{array}$ \\
\hline Shoulders & [soldəs] & {$[$ 'Jouldərz] } \\
\hline Knees & {$[$ nis] } & {$[$ ni:z] } \\
\hline Toes & {$[$ tous $]$} & {$[$ touz $]$} \\
\hline Eyes & [ais] & {$[$ aiz] } \\
\hline Nose & [nos $]$ & {$[$ nozz $]$} \\
\hline
\end{tabular}

The phoneme /ð/. The phonemes which do not exist in the Indonesian phonological sound system is the phoneme /ð/.

Consequently, the following error appears:

\begin{tabular}{|l|c|c|}
\hline $\begin{array}{c}\text { Mispronounced } \\
\text { words }\end{array}$ & $\begin{array}{c}\text { Teachers } \\
\text { pronunciation }\end{array}$ & $\begin{array}{c}\text { The standardized } \\
\text { American English } \\
\text { pronunciation }\end{array}$ \\
\hline Brother & [brada] & {$\left[\right.$ brade $\left.^{\mathrm{f}}\right]$} \\
\hline
\end{tabular}

Vowels

The phoneme /ə/. The English phoneme /a/ emerges in the word initial, medial and final positions, but the / $/$ / in Indonesian does not appear in the word final position.

\begin{tabular}{|l|l|l|}
\hline & English & Indonesian \\
\hline Initial & Above & Engkau \\
\hline Medial & Learn & Benar \\
\hline Final & Reader & - \\
\hline
\end{tabular}

\begin{tabular}{|l|l|l|}
\hline $\begin{array}{c}\text { Mispronounced } \\
\text { words }\end{array}$ & \multicolumn{1}{|c|}{$\begin{array}{c}\text { Teachers } \\
\text { pronunciation }\end{array}$} & $\begin{array}{c}\text { The standardized } \\
\text { American English } \\
\text { pronunciation }\end{array}$ \\
\hline Watermelon & [wotermelon] & {$\left[{ }^{\text {' }}\right.$ wote $^{\text {f melən }]}$} \\
\hline Brother & [brada] & {$\left[{ }^{\text {brade }}{ }^{\mathrm{f}}\right]$} \\
\hline
\end{tabular}

The phoneme /a/. The Indonesian phoneme /a/ in the sound is represented [a], and is never articulated $[Æ]$. The English phoneme /a/ has two major group words; [a:] and [Æ]. Consequently they are mispronounced as such:

\begin{tabular}{|l|l|l|}
\hline $\begin{array}{c}\text { Mispronounced } \\
\text { words }\end{array}$ & $\begin{array}{c}\text { Teachers } \\
\text { pronunciation }\end{array}$ & $\begin{array}{c}\text { The standardized } \\
\text { American English } \\
\text { pronunciation }\end{array}$ \\
\hline Banana & {$[\mathrm{ban} \Lambda \mathrm{n} \Lambda]$} & {$[\mathrm{b}$ 'n $\mathrm{n}$ Ena $]$} \\
\hline Cat & {$[\mathrm{ket}]$} & {$[\mathrm{kÆt}]$} \\
\hline
\end{tabular}

\section{Diphthongs}

Many languages, including English have vowels called dipthongs that can also be described as a sequence of two sounds, vowel + glide. The vowels sounds in the words bite [bajt] and rye [raj] are produced with the [a] vowel sound of father followed by the [j] glide, resulting in [aj]. The vowels in bout 
[bawt], brow [braw], and hour [awr] are produced by some speakers of English with similar [a] sound followed by the glide [w], [aw]. Some speakers of English produce this as [Æw], with the row unrounded vowel instead of the back vowel. The third diphthong that occurs in English is the vowel sound in boy [boj] and soil [sojl]. The mispronounced diphthong found in the data are:

\begin{tabular}{|l|l|l|}
\hline $\begin{array}{c}\text { Mispronounced } \\
\text { words }\end{array}$ & \multicolumn{1}{|c|}{$\begin{array}{c}\text { Teachers } \\
\text { pronunciation }\end{array}$} & $\begin{array}{c}\text { The standardized } \\
\text { American English } \\
\text { pronunciation }\end{array}$ \\
\hline Slice & {$[$ sles $]$} & {$[$ slais $]$} \\
\hline Nose & {$[$ nos $]$} & {$[$ noøz $]$} \\
\hline Eat & {$[$ it $]$} & {$[\mathrm{i}: \mathrm{t}]$} \\
\hline
\end{tabular}

Although there are not much difference in the pronunciation of the phoneme /e/ but the teachers pronounced the words sleeping as slipping, and the word [nis] for [ni:s]. The vowel /e/ in the words sleeping and knees are shortened, as [i:] does not exist in the Indonesian pronounciation. On the other hand, the word monkey is pronounced with a diphthong.

The results of the study also indicates the results related with suprasegmental aspect; stress are as follow:

\begin{tabular}{|l|l|l|}
\hline $\begin{array}{l}\text { Mispronounced } \\
\text { words }\end{array}$ & $\begin{array}{l}\text { Teachers } \\
\text { pronunciation }\end{array}$ & $\begin{array}{l}\text { The standardized } \\
\text { American English } \\
\text { pronunciation }\end{array}$ \\
\hline Banana & {$[$ ban $\Lambda$ 'n $\Lambda$ ] } & [bə'nÆEna] \\
\hline Tomato & {$[$ tom $\Lambda$ 'to $]$} & [to'metJo] \\
\hline
\end{tabular}

The stress in the word banana should be in the second syllable. Similar with the word tomato.

\section{CONCLUSION}

Several things can be conluded in this study:

1. The phonological system which are different in Indonesian and English leads to global errors

2. The teachers of PAUD experienced difficulties in pronouncing the consonant phonemes $/ \mathrm{p} /, / \mathrm{k} /, / \mathrm{g} /$, /d/, /s/, /ð/, and the vowel phonemes /ə/, //Е/. Diphthongs and stress are also a source of constraint.

3. Since PAUD students tend to learn by imitating their surrounding, the fact that they are in the critical age where the brain have not gone through lateralization and since teachers are role model, it is very critical that teachers avoid global errors.

4. The teachers at North Bogor have implemented the stages of using songs suggested by Millington, which is selecting a song to fit in the curriculum and culture; adaptation and modification, but in the future there is still training needed in the field of pronunciation.

\section{REFERENCES}

Brown, H. Douglas. 2001. Prinsip Pembelajaran dan Pengajaran Bahasa. (Edisi kelima). England: Longman.

2004. Prinsip Pembelajaran dan Pengajaran Bahasa. England: Longman.

Grandison, Alice. 2015. Webster's American English Dictionary (with Pronounciation Guides)

Harmer, Jeremy. 2001. The Practice of English Language Teaching. England:Longman.

Johansson, S. (2007). Seeing through Multilingual Corpora; On the Use of Corpora in Contrastive Studies (Studies in Corpus Linguistics). Amsterdam: John Benjamin.

Lakova, B. Language Interference and Methods of its Overcoming in Foreign Language Teaching. Trakia Journal of Sciences, Vol. 8, Suppl.3, pp 320-324, 2010. Trakia University. Bulgaria.

Pallawa, Baso Andi. A Comparative Study between English and Indonesian Phonological Systems. International Journal of English Language Education. 2013. Vol 1. No. 3.

Suyadi and Dalia. 2014. Implementasi dan Inovasi Kurikulum Paud 2013. Bandung: Remaja Rosdakarya.

Fabon. www.macrothink.org/journal/index.php/ijele/article/ viewFile/3892/3180

Language Education in Asia. 2011. 134-141. http://dx/ doi.org/105.5746/LEiA/11/V2/11/A11/Millington https://en.wikipedia.org/wiki/Head,_Shoulders,_K nees_and_Toes

https://ridwanderful.com/2013/11/17/sedikit-kisahmengenai-lagu-boneka-abdi/

http://en.wikipedia.org/wiki/H\%C3\%A4nschen_klein 